\title{
Akomodasi Nilai-Nilai Budaya Masyarakat Madura Mengenai Penyelesaian Carok Dalam Hukum Pidana
}

\author{
Mahrus Ali \\ Fakultas Hukum Universitas Islam Indonesia \\ J1. Tamansiswa No. 158 Yogyakarta \\ surham_02@yahoo.com
}

\begin{abstract}
This research focuses on the accomodation of cultural values of Maduranes society in solving carok problem in criminal law. Using the socio-legal research, interview, observation as the primery data, and data analysis are based on the inductive and qualitative manner, this research reveals that changing the criminal law conception as the public law into public law with the private dimension particularly in murder cases caused by self esteem defence is a must to give a chance for cultural values of Maduranes society in solving carok problem. So that, penal mediation based on the cultural values of Maduranes society as a methode to solve carok can be accomodated in criminal law by adopting some principles of traditional village or tribal moots model, victim-offender mediation model, and community panels or courts model.
\end{abstract}

Key words : carok, cultural values, and penal mediation

\begin{abstract}
Abstrak
Penelitian ini difokuskan pada persoalan akomodasi nilai-nilai budaya masyarakat Madura mengenai penyelesaian perkara carok dalam hukum pidana. Penelitian ini menggunakan metode penelitian hukum non-doktrinal dengan wawancara dan observasi sebagai data primernya. Sedangkan analisis data bersifat induktif dan kualitatif. Penelitian ini menyimpulkan bahwa akomodasi nilai-nilai budaya masyarakat Madura mengenai penyelesaian perkara carok dilakukan dengan merubah konsepsi hukum pidana menjadi hukum publik "berdimensi privat" khusus terhadap pembunuhan yang disebabkan oleh pembelaan harga diri. Perubahan tersebut menjadikan mediasi penal dalam perkara carok atas dasar nilai-nilai budaya masyarakat Madura diakomodir dalam hukum pidana melalui adopsi sebagian prinsip traditional village or tribal moots model, victim-offender mediation model, dan community panels or courts model yang sesuai dengan nilai-nilai budaya masyarakat Madura.
\end{abstract}

Kata kunci : carok, nilai-nilai budaya, dan mediasi penal 


\section{Pendahuluan}

Kajian tentang akomodasi nilai-nilai budaya masyarakat Madura mengenai penyelesaian perkara $c^{a r o k}{ }^{1}$ dalam hukum pidana penting untuk dilakukan didasarkan pada tiga alasan. Pertama, carok merupakan ekspresi pembelaan harga diri orang Madura yang dilecehkan dan terkait erat dengan nilai-nilai budaya yang dijadikan sebagai pedoman bertingkah laku. ${ }^{2}$ Sehingga eksistensinya tidak dapat disamakan dengan pembunuhan pada umumnya.

Kedua, penyelesaian perkara carok melalui hukum negara selama ini lebih menekankan pada aspek formal prosedural dengan terpenuhinya unsur-unsur delik dalam rumusan pasal yang didakwakan kepada pelaku carok. ${ }^{3}$ Hukum negara tidak memperhatikan kekhasan dan keunikan nilai-nilai budaya masyarakat Madura terutama mengenai pembelaan harga diri atau kehormatan diri, keluarga dan agama.

Ketiga, eksistensi hukum pidana sebagai salah satu instrumen penanggulangan kejahatan tidak dapat dilepaskan dari keragaman nilai-nilai budaya masyarakat di dalam menyelesaikan sengketa. Penyelesaian sengketa yang bersandar pada konstruksi berpikir hukum pidana hanya melihat sengketa pada satu aspek saja. Padahal, sengketa yang disebabkan oleh pelanggaran terhadap nilai-nilai budaya masyarakat meniscayakan kehadiran nilai-nilai budaya tersebut sebagai salah satu acuan penting agar sengketa itu dapat diselesaikan.

\section{Rumusan Masalah}

Berdasarkan tiga alasan di atas, permasalahan yang menarik untuk diteliti adalah bagaimana seyogyanya nilai-nilai budaya Masyarakat Madura mengenai penyelesaian perkara carok diakomodasi dalam hukum pidana?

\footnotetext{
${ }^{1}$ Carok adalah suatu tindakan atau upaya pembunuhan menggunakan senjata tajam -pada umumnya clurityang dilakukan oleh laki-laki terhadap laki-laki lain yang telah dianggap telah melakukan pelecehan terhadap harga diri, terutama berkaitan dengan masalah kehormatan diri, istri dan agama sehingga membuat malo (malu). Berdasarkan pengertian ini, paling tidak terdapat lima unsur yang tercakup dalam pengertain carok, yaitu tindakan atau upaya pembunuhan antar laki-laki; pelecehan harga diri, terutama berkaitan dengan kehormatan diri, perempuan dan agama; perasaan malu (malo); adanya dorongan, dukungan, serta persetujuan sosial; perasaan puas dan bangga bagi pemenangnya. A. Latif Wiyata, Carok Konflik Kekerasan dan Harga Diri Orang Madura, Cetk. Kedua, Yogyakarta, LKiS, 2006, hlm. 184

${ }^{2}$ Ibid., hlm. 170-184
} 


\section{Tujuan Penelitian}

Penelitian bertujuan untuk mengkaji, menjelaskan dan menganalisis akomodasi nilai-nilai budaya masyarakat Madura mengenai penyelesaian perkara carok dalam hukum pidana.

\section{Metode Penelitian}

Dilihat dari jenisnya ${ }^{4}$ penelitian ini termasuk ke dalam jenis penelitian hukum non-doktrinal (socio-legal research), ${ }^{5}$ karena hukum dikonsepsikan sebagai manifestasi makna-makna simbolik para pelaku sosial sebagaimana tampak dalam interaksi antar mereka. ${ }^{6}$ Titik tekannya adalah untuk menemukan teori-teori mengenai proses terjadinya dan mengenai proses bekerjanya hukum di masyarakat. ${ }^{7}$

Sumber data dalam penelitian ini berasal dari sumber primer yang terdiri dari data primer, data sekunder dan data tersier. Data primer terdiri dari studi lapangan berupa wawancara dan observasi terkait dengan bagaimana carok seyogyanya diselesaikan. Data sekunder berupa buku, disertasi, tesis, jurnal, makalah dan karya ilmiah lainnya adalah yang berkaitaan akomodasi nilai-nilai budaya masyarakat Madura mengenai penyelesaian perkara carok dalam hukum pidana. Sedangkan data tersier berupa kamus dan eksiklopedia yang menunjang data di atas.

Pengumpulan data melalui wawancara dan studi literatur, yaitu dengan menelusuri dan menelaah literatur-literatur yang terkait dengan nilai-nilai budaya masyarakat Madura, carok, dan hukum negara, dan mediasi penal berdasarkan nilainilai budaya masyarakat. Kemudian, data-data tersebut dikumpulkan, disistematisasi dan dianalisis kaitannya dengan permasalahan penelitian.

Analisis data dilakukan secara induktif dan bersifat kualitatif. Secara umum dalam analisis kualitatif terdiri dari tiga alur kegiatan yang terjadi secara bersamaan yaitu reduksi data, penyajian data, dan penarikan kesimpulan. Reduksi data diartikan

${ }^{3}$ Mahrus Ali, Dominasi Hukum Negara dalam Penyelesaian Perkara Carok Studi Konstruksi Penyelesaian Perkara Carok Berdasarkan Nilai-nilai Budaya Masyarakat Madura, Tesis, Program Pascasarjana Fakultas Hukum Universitas Islam Indonesia, Yogyakarta, 2009, hlm. 88-103

${ }^{4}$ Soetandyo Wignjosoebroto, Hukum, Paradigma, Metode dan Dinamika Masalahnya, Jakarta, HuMa, 2002, hlm. 147-176

${ }^{5}$ Tidak semua ahli hukum setuju jika socio-legal research dikategorikan sebagai penelitian hukum. Baca Peter Mahmud Marzuki, Penelitian Hukum, Cetk. Kedua, Jakarta, Kencana, 2006, hlm. 87

${ }^{6}$ Soetandyo Wignjosoebroto, Hukum....Op.Cit., hlm. 148-176

${ }^{7}$ Bambang Sunggono, Metodologi Penelitian Hukum, Cetk. Keempat, Jakarta, RajaGrafindo Persada, 2002, hlm. 
sebagai proses pemilihan, pemusatan perhatian pada penyederhanaan, pengabstrakan, dan transformasi data "kasar" yang muncul dari catatan tertulis di lapangan. Penyajian data ini bermakna sekumpulan informasi tersusun yang memberi kemungkinan adanya penarikan kesimpulan dan pengambilan tindakan. Bentuk penyajian data yang sering dilakukan adalah teks nararif. Penyajian data ini sama halnya dengan reduksi data, yaitu merupakan kegiatan analisis. ${ }^{8}$

Langkah selanjutnya adalah menarik kesimpulan berdasarkan reduksi data dan penyajian data yang dilakukan. Ketiga hal tersebut merupakan satu kesatuan yang terjalin pada saat sebelum, selama, dan setelah pengumpulan data dalam bentuk yang sejajar untuk membangun wawasan umum yang disebut analisis. Pengumpulan data merupakan prakondisi untuk terjadinya reduksi data, penyajian data, dan penarikan kesimpulan. ${ }^{9}$

\section{Hasil Penelitian dan Pembahasan}

\section{Nilai-nilai Budaya Masyarakat Madura}

Madura terkenal dengan kekhasan dan keunikan nilai-nilai budaya. ${ }^{10}$ Penggunaan istilah khas menunjuk pada pengertian bahwa entitas etnik Madura memiliki kekhususan-kultural yang tidak serupa dengan etnografi komunitas etnik lain. ${ }^{11}$ Latief Wiyata mengatakan bahwa kekhususan kultural itu tampak antara lain pada ketaatan, ketundukan, dan kepasrahan mereka secara hierarkis kepada empat figur utama dalam berkehidupan, lebih-lebih dalam praksis keberagaman. Keempat figur itu adalah Buppa', Babbu, Guru, ban Rato (ayah, ibu, guru, dan pemimpin pemerintahan). ${ }^{12}$

Selain terkenal dengan budayanya yang khas, Madura juga terkenal dengan keunikan budaya yang dalam hal ini tampak pada perilaku dalam memelihara jalinan

\footnotetext{
${ }^{8}$ Matthew B. Miles dan A. Michael Huberman, Analisis Data Kualitatif, tanpa Penerbit, tt, hlm 16

${ }^{9}$ Ibid., hlm. 20

${ }^{10}$ Nilai-nilai budaya merupakan nilai- nilai yang disepakati dan tertanam dalam suatu masyarakat, lingkup organisasi, lingkungan masyarakat, yang mengakar pada suatu kebiasaan, kepercayaan (believe), simbol-simbol, dengan karakteristik tertentu yang dapat dibedakan satu dan lainnya sebagai acuan perilaku dan tanggapan atas apa yang akan terjadi atau sedang terjadi. Koentjaraningrat, Kebudayaan, Mentalitas dan Pembangunan,Cetk. Keduapuluh, Jakarta: Gramedia Pustaka Utama, 2002, hlm. 25

${ }^{11}$ Hasan Alwi, Kamus Besar Bahasa Indonesia, Edisi Ketiga, Jakarta, Departemen Pendidikan Republik Indonesia dan Balai Pustaka, 2001, hlm. 563

${ }^{12}$ A. Latief Wiyata, Madura yang Patuh?; Kajian Antropologi Mengenai Budaya Madura, Jakarta, CERIC-FISIP UI, 2003, hlm. 1
} 
persaudaraan sejati. Hal ini tergambar dari ungkapan budaya oreng dhaddhi taretan, taretan dhaddhi oreng (orang lain dapat menjadi atau dianggap sebagai saudara sendiri, sedangkan saudara sendiri dapat menjadi atau dianggap sebagai orang lain). ${ }^{13}$ Bagi masyarakat Madura, persaudaraan tidak selalu identik dengan hubungan darah kekerabatan, tetapi juga pada pertemanan. Persaudaraan yang mungkin masih satu rumpun keluarga, dapat saja berubah menjadi permusuhan disebabkan adanya persoalan yang tidak dapat diselesaikan secara kekeluargaan. Relasi seperti itu, lalu secara kolektif biasa disebut dengan teman (kanca) dan musuh (moso). Teman merupakan relasi sosial dengan tingkat keakraban paling tinggi. Sebaliknya, musuh merupakan relasi sosial dengan tingkat keakraban paling rendah. ${ }^{14}$

Masyarakat Madura juga dikenal dengan karakteristik yang menonjol, yaitu karakter apa adanya. Sifat masyarakat Madura ekspresif, spontan, dan terbuka. Ekspresivitas, spontanitas, dan keterbukaan orang Madura, senantiasa termanifestasikan ketika harus merespon segala sesuatu yang dihadapi, khususnya terhadap perlakuan orang lain atas dirinya. Dengan karakteristik yang demikian, sebenarnya nilai-nilai budaya Madura membuka peluang bagi ekspresi individual secara lebih transparan.

Bagi orang Madura harga diri merupakan nilai budaya yang hingga saat ini masih dijunjung tinggi. Harga diri adalah nilai yang mendasar bagi orang Madura dan menjadi ukuran eksistensi diri. Oleh karenanya, harga diri merupakan hal penting yang harus dipertahankan agar tidak direndahkan. ${ }^{15}$ Orang Madura yang dilecehkan harga dirinya akan merasa malo (malu) kemudian melakukan carok terhadap orang yang melecehkan itu. Pelecehan harga diri sama artinya dengan pelecehan terhadap kapasitas diri. ${ }^{16}$

Demikian halnya dengan nilai kesopanan. Penghormatan orang Madura terhadap nilai-nilai kesopanan sangat tinggi. Begitu pentingnya nilai kesopanan sehingga terdapat banyak ungkapan yang berkaitan dengan hal tersebut. Misalnya ungkapan ta'tao batona langgar (tidak pernah merasakan lantainya langgar) mencerminkan suatu ungkapan bahwa seseorang belum pernah masuk langgar dan mengaji atau belum pernah tinggal di pondok pesantren, sehingga tidak mengenal

\footnotetext{
${ }^{13}$ A. Latief Wiyata, Carok...., hlm. 61

${ }^{14}$ Ibid., hlm. 60

${ }^{15}$ Bambang Sambu Badriyanto, Karakteristik Etnik dan Hubungan Antar Etnik, Ringkasan Hasil Penelitian,

${ }^{16}$ Ibid., hlm. 170-171
} Universitas Jember, tt, hlm. 8 
tatakrama atau kesopanan. Ungkapan ini ditujukan untuk orang-orang yang melanggar nilai-nilai kesopanan dalam masyarakat Madura.

Masyarakat Madura tidak dapat dipisahkan dari ajaran-ajaran Islam dalam kehidupan sehari-hari. Islam dan Madura seperti dua hal yang tidak dapat dipisahkan dan berhubungan dengan erat satu sama lain. Perilaku orang Madura begitu kental dengan ajaran-ajaran Islam. Ajaran-ajaran Islam memberikan kontribusi yang cukup besar terhadap pembentukan nilai-nilai budaya masyarakat Madura. ${ }^{17}$

Nilai-nilai Islam menjadi salah satu sifat yang mendefinisikan orang Madura, sehingga dengan demikian bahwa orang Madura pasti beragama Islam. Sebuah gambaran yang menunjukkan bahwa orang Madura berjiwa agama Islam terdapat ungkapan abantal syahadat, asapo iman, apayung Allah (dalam kehidupan mereka memakai syahadat sebagai alas kepala, berselimut iman, dan berlindung kepada Allah, niscaya akan selamat). Menghina agama sama halnya menyinggung harga diri (apote tolang), hukumnya adalah mati. Status seseorang bagi orang Madura dilihat dari kadar ke-Islaman yang melekat pada dirinya. Simbol agama Islam tertinggi yang dipakai sebagai patokan adalah kiai dan kemudian haji. ${ }^{18}$

\section{Carok dan Proses Penyelesaiannya Berdasarkan Musyawarah}

Orang Madura sejak lama terbiasa menyelesaikan konflik yang terjadi dengan mengutamakan adanya musyawarah, baik di dalam hubungan kekerabatan dan ketetanggaan maupun yang berkaitan dengan persoalan lain. Di dalam penyelesaian konflik tersebut selalu diutamakan musyawarah, perdamaian, dan saling memaafkan serta tidak tergesa-gesa untuk langsung menyerahkannya ke peradilan negara. ${ }^{19}$

Budaya musyawarah selain lebih mendekatkan orang Madura satu sama lain juga dimaksudkan untuk memulihkan keseimbangan yang disebabkan oleh konflik. Kehadiran hukum negara dengan seperangkat karakteristiknya tidak saja menjadikan orang Madura sebagai orang yang suka bermusuhan, tapi juga menyebabkan konflik tersebut berkesinambungan. Kehadiran hukum negara membawa beban bagi nilainilai budaya masyarakat Madura. ${ }^{20}$

\footnotetext{
${ }^{17}$ Mien Ahmad Rifai, Manusia Madura Pembawaan, Perilaku, Etos Kerja, Penampilan, dan Pandangan Hidupnya seperti Dicitrakan Peribahasanya, Yogyakarta, Pilar Media, 2007, hlm. 347

${ }^{18}$ Bambang Sambu Badriyanto, Op.Cit., hlm. 7

${ }^{19}$ Hilman Hadikusuma, Pengantar Ilmu Hukum Adat Indonesia, Bandung, Mandar Maju, 1992, hlm. 38

${ }^{20}$ M. Syamsudin, "The Burden of Indigenous People In Dealing with State Regulation", Jurnal Hukum, Vol. 15 No. 3, 2008
} 
Beban tersebut disebabkan oleh suatu realitas bahwa orang Madura terkenal dengan kebersamaannya yang kuat. Ikatan-ikatan kemasyarakatan sudah melembaga di Madura, sehingga muncul ungkapan oreng dedhi kancah (orang lain menjadi teman). Seluruh kehidupan orang Madura diliputi oleh rasa kebersamaan, segala sesuatunya dengan memperhatikan kepentingan bersama anggota keluarga, kerabat, dan tetangga atas dasar tolong menolong, saling membantu antara satu sama lain. ${ }^{21}$ Setiap individu dan anggota masyarakat merupakan bagian integral dari masyarakat Madura secara keseluruhan. ${ }^{22}$

Di dalam rasa kebersamaan ini terdapat pula rasa persatuan, hubungan yang erat, dan senasib sepenanggungan. ${ }^{23}$ Hal-hal demikian yang menjadikan mengapa budaya musyawarah dan saling memaafkan menjadi penting dihidupkan kembali dalam menyelesaikan perkara carok di Madura. Oleh karena itu, ditolak pendapat yang mengatakan bahwa eksistensi nilai-nilai budaya masyarakat Madura di dalam menyelesaikan perkara carok memiliki kedudukan yang lebih rendah dibandingkan dengan kedudukan hukum negara dengan karakteristiknya yang formal. ${ }^{24}$ Pendapat inilah yang juga secara langsung mematikan budaya musyawarah orang Madura terutama ketika terjadi konflik.

Dengan demikian, yang pertama kali dilakukan dalam upaya menyelesaikan perkara carok berdasarkan nilai-nilai budaya Madura adalah dengan memberi peluang bagi diakuinya budaya musyawarah sebagai bagian dari nilai-nilai budaya masyarakat Madura. Upaya ini dapat berhasil bila dominasi hukum negara dalam segala aspeknya diminimalisir. Tidak semua konflik (carok) yang terjadi di Madura secara serta merta diselesaikan melalui prosedur dan proses yang disediakan hukum negara, tapi dengan menjadikan nilai-nilai budaya masyarakat Madura, seperti musyawarah, sebagai "alat" untuk memandunya.

\section{Hukum Pidana Sebagai Hukum Publik "Berdimensi Privat"}

Dalam konteks hukum pidana, peluang diakuinya budaya musyawarah sebagai bagian dari nilai-nilai budaya masyarakat Madura dalam penyelesaian perkara carok hanya mungkin terjadi jika konsepsi hukum pidana sebagai hukum publik

\footnotetext{
${ }^{21}$ Hilman Hadikusuma, Pokok-pokok Pengertian Hukum Adat, Bandung, Alumni, 1980, hlm. 54

${ }^{22}$ Otje Salman Soemadiningrat, Rekonseptualisasi Hukum Adat Kontemporer, Bandung, Alumni, 2002, hlm. 31

${ }^{23}$ Ibid., hlm. 55

${ }^{24}$ Abdurrahman, Kedudukan Hukum Adat dalam Rangka Pembangunan Nasional, Bandung, Alumni, 1978, hlm.
} 
dimodifikasi. Modifikasi tersebut di satu sisi dikaitkan dengan segi teoritis serta kenyataan dalam praktik dan di sisi lain dikaitkan dengan eksistensi nilai-nilai budaya masyarakat yang masih berlaku dan dipertahankan. Hukum pidana adalah hukum publik yang "berdimensi privat". Makna privat di sini berkaitan dengan pelanggaran yang ada hubungannya dengan nilai-nilai budaya masyarakat seperti pada perkara carok yang disebabkan oleh pembelaan harga diri.

Implikasi yang muncul dari konsep tersebut adalah pelanggaran, proses penyelesaian, pihak yang berhak menyelesaikan, dan penjatuhan hukuman tidak lagi didominasi oleh hukum negara dan aparat penegak hukumnya, tapi nilai-nilai budaya masyarakat beserta orang-orang yang dianggap memiliki otoritas dan kharisma juga diakui eksistensinya untuk menyelesaikan pelanggaran yang dikategorikan sebagai pelanggaran terhadap nilai-nilai budaya. Dalam hubungan ini, nilai-nilai budaya masyarakat Madura dalam proses penyelesaian perkara carok memiliki tempat yang berarti dalam hukum pidana. Dengan demikian, akomodasi nilai-nilai budaya Madura mengenai carok dalam hukum pidana hanya dapat terwujud jika konsepsi hukum pidana tidak lagi sebagai bagian dari hukum publik, tapi hukum publik yang "berdimensi privat".

\section{Mediasi Penal atas Dasar Nilai-nilai Budaya Masyarakat Madura}

Ketika hukum pidana dikategorikan sebagai hukum publik yang "berdimensi privat", maka penyelesaian perkara carok di luar pengadilan negara berdasarkan nilai-nilai budaya masyarakat Madura memiliki dasar yang kuat di dalam hukum pidana. Bangunan hukum pidana tidak lagi bersifat eksklusif dengan memberikan otoritas penuh kepada negara untuk menentukan perbuatan-perbuatan apa saja yang dilarang dan hanya aparat penegak hukum yang berhak menyelesaikannya, tapi membuka diri terhadap proses penyelesaian sengketa di luar pengadilan. Mediasi yang selama ini hanya dapat diterapkan dalam perkara perdata dan merupakan hal yang tabu bahkan "diharamkan" penerapannya dalam hukum pidana, difungsionalisasikan dalam penyelesaian perkara carok.

Stuart M. Widman mendefisikan mediasi sebagai a process in which a mediator facilitates communication and negotiation between parties to assist them in reaching a voluntary agreement regarding their dispute, ${ }^{25}$ suatu proses di mana seorang mediator

${ }^{25}$ Stuart M. Widman, "The Protections and Limits of Confidentiality in Mediation", Alternatives to the High Cost of Litigation, November, 2006, hlm. 161 
memfasilitasi terjadinya komunikasi dan negosiasi antara para pihak agar tercapai kesepakatan mengenai sengketa yang mereka hadapi.

Mediasi dalam hukum pidana berbeda dengan mediasi dalam hukum perdata, yaitu berkaitan dengan apa yang dipertaruhkan/dipermasalahkan, siapa yang terlibat dan siapa yang menjadi mediator. Dalam hukum perdata mediasi biasanya berkaitan dengan masalah uang, sedangkan dalam hukum pidana yang dipermasalahkan lebih banyak pada kebebasan dan kehidupan seseorang. Mengenai siapa yang terlibat dalam mediasi, dalam hukum perdata biasanya para pihak yang secara langsung bersengketa atau pihak kedua yang berkepentingan. Sedangkan dalam hukum pidana yang terlibat lebih kompleks tidak hanya pelaku dan korban, tapi juga jaksa penuntut umum, serta masyarakat luas. Mediator dalam hukum perdata umumnya orang-orang yang sudah mendapatkan pelatihan untuk itu, sedangkan dalam hukum pidana, mediator umumnya adalah hakim atau orang lain yang tidak memiliki pengalaman, pelatihan, bahkan pemahaman nyata praktik mediasi. ${ }^{26}$

Dalam hukum pidana mediasi berarti proses penyelesaian perkara pidana dengan mempertemukan pelaku kejahatan dan korban untuk mencapai kesepakatan bersama berkaitan dengan kejahatan yang dilakukan pelaku dan restitusi yang diberikan kepada korban. ${ }^{27}$ Pertemuan itu diperantarai oleh seorang mediator atau lebih baik berasal dari penegak hukum, pemerintah, orang yang bergerak di bidang lembaga swadaya masyarakat, maupun tokoh masyarkat. ${ }^{28}$

Dipertemukannya pelaku dan korban kejahatan secara langsung mengubah cara pandang hukum pidana yang selama ini dikenal statis di dalam menyelesaikan sengketa dengan proses dan prosedur yang tetap,,$^{29}$ ke arah hukum pidana yang humanistis. Karena di dalam mediasi fokus utamanya bukan pada pembalasan terhadap tindakan pelaku, tapi pada upaya penyembuhan dan perdamaian. Pertemuan antara pelaku dan korban bertujuan untuk memperbaiki kerusakan atau kerugian, baik terhadap korban, lingkungan maupun masyarakat luas. ${ }^{30}$

${ }^{26}$ Maureen E. Laflin, "Remarks On Case-Management Criminal Mediation”, Idaho Law Review, No. 40, 2004, hlm. 573

${ }^{27}$ Mark William Bakker, "Repairing The Breach and Reconciling the Discordant: Mediation in the Criminal Justice System”, North Carolina Law Review, No. 72, 1994, hlm 1483; Gabriel H. Teninbaum, "Easing The Burden: Mediating Misdemeanor Criminal Matters”, Dispute Resolution Journal, No. 62, 2007, hlm. 64

${ }^{28}$ Mark William Bakker, Op.Cit., hlm. 1485

${ }^{29}$ Jack B. Weinstein, "Some Benefit and Risks of Privatization of Justice Though ADR", Obio State Journal on Dispute Resolution, 1996, hlm. 292

${ }^{30}$ Mary Ellen Reimund, "Mediation in Criminal Justice: A Restorative Approach", Advocate, No. 46, 2003, hlm. 22 
Dewasa ini penggunaan mediasi dalam sistem peradilan pidana tumbuh dan berkembang sangat pesat. Beberapa ahli hukum pidana menyerukan perlunya diadakan program-program yang bertujuan mempertemukan korban dan pelaku sehingga masalah yang mereka hadapi dapat diselesaikan dengan baik dan situasi kembali berjalan dengan normal. ${ }^{31}$ Seruan tersebut didasari bahwa sistem peradilan pidana terlalu positivistik dan hanya bertujuan untuk memberikan balasan yang setimpal kepada pelaku kejahatan atas perbuatan yang dilakukan, sehingga muncul ketidakpuasan dan ketidakadilan. ${ }^{32}$

Peradilan pidana juga bukan merupakan institusi yang paling baik di dalam menyelesaikan konflik antara korban dan pelaku. Sebab, peradilan pidana ternyata memiliki standar keadilan tersendiri terhadap pelaku kejahatan yang sama sekali tidak memperhatikan keinginan-keinginan korban. ${ }^{33}$ Penyelesaian konflik juga akan merusak hubungan kekeluarkan oleh korban dan pelaku. Hubungan yang awalnya damai, tentram, harmonis dan bersifat kekeluargaan hancur dengan kehadiran sistem peradilan pidana. ${ }^{34}$

Atas dasar beberapa kelemahan tersebut, mereka mengusulkan agar proses penyelesaian konflik tidak hanya berada di tangan peradilan pidana tapi dengan mengefektifkan eksistensi mediasi, karena memiliki kelebihan yang tidak ditemukan dalam sistem peradilan pidana. Pertama, mediasi akan mengurangi perasaan balas dendam korban, lebih fleksibel karena tidak harus mengikuti prosedur dan proses sebagaimana dalam sistem peradilan pidana, dan lebih sedikit menghabiskan biaya, serta prosesnya lebih cepat dibandingkan dengan proses litigasi. ${ }^{35}$

Kedua, beban sistem peradilan pidana karena menumpuknya perkara dan proses penyelesaianya memakan waktu yang tidak sedikit banyak dapat dikurangi dengan kehadiran mediasi antara pelaku dan korban. ${ }^{36}$ Ketiga, mediasi memberikan kesempatan kepada korban bertemu dengan pelaku untuk membahas kejahatan yang telah merugikan kehidupannya, mengungkapkan perhatian dan perasaannya serta

\footnotetext{
${ }^{31}$ Mark William Bakker, Repairing... Op.Cit., hlm. 1480

${ }^{32}$ Ibid.

33 Adina Levine, "A Dark State of Criminal Affairs: ADR Can Restore Justice to the Criminal "Justice" System", Hamline Journal of Public Law and Policy, 2003, hlm 390; Nancy A. Welsh, "The Place of Court-Connected Mediation In A Democratic Justice System”, Cardozo Journal of Conflict Resolution, No. 5, 2004, hlm. 118

${ }^{34}$ Jack B. Weinstein, Op.Cit., hlm. 294

${ }_{35}$ Mark William Bakker, Op.Cit

${ }^{36}$ Larysa Simms, "Criminal Mediation is The Base of the Criminal Justice System: Not Replacing Traditional Criminal Adjudication, Just Making it Better”, Ohio State Journal on Dispute Resolution, No. 22, 2007, hlm 801; Jack B. Weinstein, Op.Cit., hlm. 293
} 
meminta adanya restitusi. ${ }^{37}$ Keempat, mediasi menciptakan kembali hubungan yang harmonis antara korban dan pelaku. Kondisi ini tidak ditemukan di dalam penyelesaian konflik melalui sistem peradilan pidana. Pemberian maaf korban kepada pelaku akan mengurangi rasa bersalah pelaku dan menciptakan rekonsiliasi antara keduanya. ${ }^{38}$

Berdasarkan uraian di atas, akomodasi nilai-nilai budaya masyarakat Madura mengenai penyelesaian perkara carok dilakukan dengan membuat suatu payung hukum yang memungkinkan perkara carok diselesaikan melalui mediasi penal dengan tetap memperhatikan eksistensi nilai-nilai budaya Masyarakat Madura. Payung hukum tersebut diletakkan baik dalam hukum pidana materiil maupun hukum pidana formil. Selain itu, model-model mediasi yang selama ini dikenal dapat dijadikan sebagai acuan formulasi penyelesaian perkara carok berdasarkan mediasi penal dalam hukum pidana. Paling tidak terdapat tiga model mediasi penal dalam konteks ini, yaitu traditional village or tribal moots model, ${ }^{39}$ victim-offender mediation model ${ }^{40}$ dan community panels or courts model..$^{41}$ Prinsip-prinsip kerja tiga model tersebut tidak diambil semua, melainkan sebagian saja yang sesuai dengan nilai-nilai budaya masyarakat Madura.

${ }^{37}$ Mary Ellen Reimund, "Confidentiality in Victim-Offender Mediation: A False Promise?”, Journal of Dispute Resolution, 2005, hlm. 404

${ }^{38}$ Jennifer Gerarda Brown, "The Use of Mediation to Resolve Criminal Cases: A Procedural Critique", Emory Law Journal, No. 43, 1994, hlm. 1277

${ }^{39}$ Menurut model ini seluruh anggota masyarakat bertemu untuk memecahkan konflik kejahatan di antara warganya. Penerapan model ini terdapat di negara-negara berkembang dan umumnya di daerah pedesaan atau pedalaman. Titik tekan model ini lebih pada manfaat yang ingin dicapai oleh masyarakat yang berada di wilayah itu. Tujuan utamanya adalah agar ketenangan dan kedamaian tercipta kembali dengan berlandaskan keyakinan agama dan keutuhan kultural. Barda Nawawi Arief, "Mediasi Penal dalam Penyelesaian Sengketa di Luar Pengadilan", makalah disampaikan pada Seminar Nasional Pertanggungjawaban Hukum Korporasi dalam Konteks Good Corporate Governance, Program Doktor Ilmu Hukum UNDIP, Jakarta, 27 Maret 2007, hlm. 25

${ }^{40}$ Fokus utama Victim Offender Mediation adalah menempatkan pelaku dan korban kejahatan sebagai bagian dari sistem peradilan pidana. Korban diberi hak untuk bertanya kepada pelaku mengapa dia menjadi korban, tujuannya adalah agar pelaku bertanggungjawab atas tindakannya. Pelaku juga diminta bertanggungjawab atas tindakannya yang merugikan korban. Selain itu, konflik antara keduanya dapat diselesaikan dengan hasil yang sama-sama diterima oleh kedua belah pihak. Semua itu dapat terwujud jika permaafan dijadikan sebagai basis utama, artinya, di satu sisi pelaku mengakui bahwa tindakannya yang merugikan korban merupakan perbuatan yang salah, meminta maaf kepada korban serta siap bertangungjawab atas semua kerugian yang dialami korban, sedangkan pada sisi yang lain, korban menerima permintaan maaf pelaku. Permaafan mensyaratkan adanya kemauan seseorang untuk menerima hak orang lain untuk memarahi, memperoleh penilaian negatif, dan perilaku tidak berkenan yang disebabkan oleh ketidakadilannya pada orang itu. Maureen E. Laflin, "Remarks on Case-Management Criminal Mediation", Idaho Law Review, No. 40, 2004, hlm 581; Ilyssa Wellikoff, "Victim-Offender Mediation and Violent Crimes: On the Way to Justice”, Cardozo Online Journal of Conflict Resolution, No. 5, 2004, hlm. 6

${ }^{41}$ Model ini merupakan program untuk membelokkan kasus pidana dari penuntutan atau peradilan pada prosedur masyarakat yang lebih fleksibel dan informal dan sering melibatkan unsur mediasi atau negosiasi. Dalam model ini pejabat lokal dapat mempunyai lembaga/badan tersendiri untuk mediasi itu. Barda Nawawi Arief, Op.Cit., hlm. 28 
Dalam tribal moots model aspek kesukuan yang berlandaskan keyakinan agama dan keutuhan kultural dalam penyelesaian sengketa berdasarkan mediasi sesuai dengan nilai-nilai budaya masyarakat Madura dengan kekhasan dan keunikan budayanya, serta kuatnya pengaruh ajaran agama Islam dalam kehidupan sosialkultural mereka. ${ }^{42}$ Mediasi berdasarkan tribal moots model tetap berpegang teguh pada nilai-nilai budaya masyarakat Madura.

Prinsip kerja yang diambil dalam victim-offender mediation model (VOM) adalah pada fase mediasi, terutama fase ketiga, yaitu fase mediasi itu sendiri dengan modifikasi dan fase keempat, yaitu pelaksanaan hasil kesepakatan. Modifikasi terletak pada menjadikan pemberian restitusi sebagai hal yang sama-sama penting kepada keluarga korban dengan tujuan utama mediasi yaitu penyelesaian sengketa. Pemberian sejumlah uang oleh pelaku kepada keluarga korban merupakan hal yang penting dalam upaya meringankan beban mereka dalam menyelenggarakan acara tahlilan $^{43}$ dan kelangsungan hidup mereka. Sedangkan fase pertama dan kedua tidak dapat dijadikan sebagai bahan formulasi mediasi penal perkara carok berdasarkan nilai-nilai budaya masyarakat Madura. ${ }^{44}$ Terdapat tiga alasan yang dapat dikemukakan;

Pertama, dalam perkara carok, salah satu pihak pasti ada yang meninggal. Tidak dapat disebut perkara carok jika kedua belah pihak dalam keadaan hidup. Sebab, di samping menitikberatkan pada motif dan senjata yang digunakan yang harus berupa clurit, carok harus mengakibatkan matinya salah satu pihak. Hal demikian ternyata tidak ditemukan dalam victim-offender mediation model karena baik pelaku maupun korban kejahatan sama-sama bertemu, dalam arti masih hidup. Dalam carok pihak yang bersengketa adalah pelaku dan keluarga korban. Keluarga di sini adalah keluarga dekat seperti ayah, istri, dan anak, dan keluarga jauh seperti tetangga dekat dan familinya.

Kedua, dalam VOM konfrontasi oleh mediator didahului oleh pertemuan mediator dengan para pihak dalam waktu yang terpisah atau menghubunginya melalui

${ }^{42}$ Mien Ahmad Rifai, Manusia..., Op.Cit., hlm. 44-49

${ }^{43}$ Tablilan merupakan suatu acara yang di dalamnya berisi pembacaan al-Qur'an, sholawat dan do'a yang secara khusus ditujukan kepada orang yang meninggal dunia agar diampuni segala dosanya oleh Tuhan yang Maha Esa dan keluarga yang ditinggalkan mendapatkan kesabaran atas musibah yang menimpa. Yang menghadiri tablilan ini biasanya para sanak keluarga orang yang meninggal dan seluruh masyarakat di desa yang bersangkutan yang dimpimpin langsung oleh seorang kiai

${ }^{44}$ Fase pertama adalah fase masukan (in take). Pada fase ini mediator mempelajari konflik dari para pihak dan harus menentukan apakah pelanggaran yang para pihak memang dapat diadakan mediasi. Sedangkan fase kedua adalah fase persiapan konfrontasi. Alyssa H. Shenk, "Victim-Offender Mediation: The Road To Repairing Hate Crime Injustice", Obio State Journal on Dispute Resolution No. 17, 2001, hlm. 194-195 
telpon atau pos. ${ }^{45} \mathrm{Hal}$ demikian ternyata tidak dapat diterapkan dalam mediasi penal perkara carok. Sosok kiai dan bejing tengka ${ }^{46}$ bukan orang bagi pelaku carok dan keluarga korban, karena memang memiliki kedudukan yang sentral dan peran yang sangat penting dalam penyelesaian sengketa.

Ketiga, mediator dalam perkara carok didasarkan pada kharisma dan peran mereka dalam masyarakat. Sosok kiai bagi masyarakat Madura terkenal dengan kharisma, kedalaman ilmu agama, dan memiliki perangai yang bagus. Sedangkan sosok bejing tengka terkenal dengan kharismanya terutama bagi sesama bejing. Kedua hal ini tidak ditemukan dalam model VOM karena mediator ternyata tidak dikenal oleh korban dan pelaku kejahatan.

Prinsip kerja lain dalam model VOM yang tidak dapat diterapkan dalam perkara carok adalah ruang lingkup tindak pidana yang dapat diselesaikan secara mediasi. Dalam carok tindakan pelaku dikategorikan sebagai pembunuhan korban pasti meninggal dunia, sedangkan dalam model VOM tindak pidana yang dapat dimediasi hanya terbatas pada tindak pidana yang tidak ada hubungannya dengan penghilangan nyawa. ${ }^{47}$ Selain itu, penyelenggaraan mediasi penal berdasarkan model VOM masih di dalam sistem peradilan pidana, sedangkan mediasi penal dalam perkara carok berada di luar sistem peradilan pidana. Fungi sistem peradilan pidana dalam mediasi penal perkara carok hanya menjustifikasi penyelesaian perkara carok berdasarkan nilai-nilai budaya masyarakat Madura.

Dalam community panels or courts prinsip kerja yang diambil berkenaan dengan pembelokan perkara pidana dari penuntutan dan peradilan pada prosedur masyarakat yang lebih informal dan fleksibel. Dengan prinsip ini, maka perkara carok memang diselesaikan di luar pengadilan dengan prosedur dan proses yang informal dan fleksibel, melibatkan kiai dan bejing tengka sebagai mediatornya, dan bertujuan menciptakan perdamaian antara pelaku carok dan keluarga korban.

Ada tiga keuntungan jika nilai-nilai budaya masyarakat mengenai penyelesaian sengketa (pidana) diakomodir dalam hukum pidana. Pertama, nilai-nilai budaya

\footnotetext{
${ }^{45}$ Russell E. Farbiarz, "Victim-Offender Mediation: A New Way of Disciplining America's Doctors”, Michigan State University Journal of Medicine \& Law, No.12, 2008, hlm. 366

${ }^{46}$ Bejing tengka adalah seseorang yang pernah melakukan carok kemudian tidak melakukannya lagi dan berubah menjadi orang baik, memiliki olah kanuragan, kemampuan ekonomi dan kharisma yang kuat di masyarakat.

${ }^{47}$ Victim Offender Mediation umumnya diterapkan pada tindak pidana seperti tindak pidana harta benda, tindak pidana penghinaan, pelukaan ringan, penghinaan atas dasar ras, agama, dan pelecehan seksual. Bahkan, saat ini VOM cenderung diterapkan pada tindak pidana yang menimbulkan luka dan kerugian yang besar pada korban. Alyssa H. Shenk, Victim-Offender Mediation..., Op.Cit., hlm. 194-209
} 
masyarakat tetap lestari dan diakui eksistensinya terutama berkaitan dengan penyelesaian sengketa. Selama ini peranan hukum pidana adat yang berdasarkan nilai-nilai budaya masyarakat dieliminir oleh kehadiran hukum negara. Undangundang No. 1/Drt/1951 secara langsung hendak menghapus hukum pidana adat berikut sanksi-sanksi adat dari sistem hukum di Indonesia dan diganti oleh peraturan perundang-undangan sehingga prosedur penyelesaian perkara-perkara pidana pada umumnya disalurkan melalui peradilan negara (umum). ${ }^{48}$ Dalam konteks ini, dengan diakomodasinya nilai-nilai budaya mengenai penyelesaian sengketa melalui mediasi penal, maka eksistensi nilai-nilai tetap lestari dan diakui eksistensinya.

Kedua, sebagai akibat dari yang pertama yakni keberadaan hukum negara yang dalam banyak hal bertentangan dengan nilai-nilai budaya masyarakat, ${ }^{49}$ maka penyelesaian perkara melalui mediasi penal berdasarkan nilai-nilai budaya masyarakat akan menyebabkan hubungan antara hukum negara dan nilai-nilai budaya masyarakat mengalami perubahan mendasar, yaitu berjalan secara harmonis dan saling melengkapi.

Ketiga, penyelesaian sengketa melalui mediasi pidana berdasarkan nilai-nilai budaya masyarakat akan mengurangi beban sistem peradilan pidana. Dewasa ini sistem peradilan pidana mengalami kelebihan beban perkara sehingga hal itu mengurangi efektifitasnya di dalam menanggulangi kejahatan. ${ }^{50}$

Penyelesaian perkara carok berdasarkan nilai-nilai budaya masyarakat Madura yang diakomodasi hukum pidana dalam bentuk mediasi penal, sesungguhnya juga berpeluang untuk meminimalisir terjadinya carok di Madura. Selama ini, salah satu penyebab mengapa balas dendam kematian anggota keluarga akibat carok terus terjadi adalah karena pendekatan yang ditempuh hukum negara tidak memperhatikan nilai-nilai budaya masyarakat Madura. Hukum negara memandang carok dalam bingkai yang positivistik. ${ }^{51}$ Akibatnya, masyarakat menilai bahwa penyelesaian carok berdasarkan hukum negara tidak memuaskan sehingga perlu dicari alternatif lain penyelesaian carok yang sesuai dengan kontruksi orang Madura dan nilai-nilai budaya yang dianut dan dijadikan pedoman dalam bertingkah laku.

\footnotetext{
${ }^{48}$ Otje Salman Soemadiningrat, Rekonseptualisas...,.Op.Cit., hlm. 155

${ }^{49}$ Sahetapy, Kausa Kejahatan dan Beberapa Analisa Kriminologik, Bandung: Alumni, 1981, hlm. 85-86

${ }^{50}$ David Code, "The Paradox of Race and Crime: a Comment on Randall Kennedy's "Politics of Distinction”, Georgetown Law Journal, No. 83, 1995, hlm. 2555

${ }^{51}$ Bagya Agung Prabowo, M. Syamsudin, dan Mahrus Ali, Carok di Madura Studi tentang Aliran Hukum yang Dianut Hakim di dalam Memutus Perkara Carok, Penelitian Institusional, Pusat Studi Hukum Fakultas Hukum Universitas Islam Indonesia, Yogyakarta, 2009, hlm. 44-59
} 


\section{Penutup}

Penelitian ini menyimpulkan bahwa akomodasi nilai-nilai budaya masyarakat Madura mengenai penyelesaian perkara carok dalam hukum pidana dilakukan dengan merubah konsepsi hukum pidana menjadi hukum publik "berdimensi privat" khusus terhadap pembunuhan yang disebabkan oleh carok. Perubahan tersebut menjadikan mediasi penal dalam perkara carok atas dasar nilai-nilai budaya masyarakat Madura diakomodir dalam hukum pidana melalui adopsi beberapa prinsip tribal mootes model, victim-offender mediation model, dan community panels or courts model yang cocok dan sesuai dengan nilai-nilai budaya masyarakat Madura.

Pengaturan mediasi penal tersebut diletakkan dalam hukum pidana materiil dan hukum pidana formal. Pengaturan mediasi penal memiliki tiga keuntungan. Pertama, nilai-nilai budaya masyarakat tetap lestari dan diakui eksistensinya terutama berkaitan dengan penyelesaian sengketa. Selama ini peranan hukum pidana adat yang berdasarkan nilai-nilai budaya masyarakat dieliminir oleh Pasal 5 ayat 3 sub b Undang-undang No. 1/Drt/1951. Kedua, sebagai akibat dari yang pertama, maka keberadaan hukum negara yang dalam banyak hal bertentangan dengan nilai-nilai budaya masyarakat, maka penyelesaian perkara melalui mediasi penal berdasarkan nilai-nilai budaya masyarakat akan menyebabkan hubungan antara hukum negara dan nilai-nilai budaya masyarakat mengalami perubahan mendasar, yaitu berjalan secara harmonis dan saling melengkapi. Ketiga, penyelesaian sengketa melalui mediasi pidana berdasarkan nilai-nilai budaya masyarakat akan mengurangi beban sistem peradilan pidana.

Penelitian ini menyarankan; pertama, pemahaman orang Madura terhadap ajaran agama Islam yang tekstual dan fanatik terutama di dalam memaknai pentingnya perlindungan agama, keturunan, harta, jiwa, dan akal perlu dirubah. Karena pemahaman yang demikian secara tidak langsung mempersubur praktik penyelesaian suatu permasalahan melalui carok; kedua, peningkatan pemahaman orang Madura tentang pendidikan hukum yang tidak hanya menekankan aspek formalitas dan bersifat birokratis seyogyanya dijadikan sebagai program pemerintah yang berkesinambungan sehingga perkara carok dapat diminimalisir. 


\section{Daftar Pustaka}

A. Latief Wiyata, Madura yang Patuh?; Kajian Antropologi Mengenai Budaya Madura, Jakarta, CERIC-FISIP UI, 2003.

, Carok Konflik Kekerasan dan Harga Diri Orang Madura, Cetk. Kedua, Yogyakarta, LKiS, 2006.

A. Welsh, Nancy, "The Place of Court-Connected Mediation In A Democratic Justice System", Cardozo Journal of Conflict Resolution, No. 5, 2004.

Abdurrahman, Kedudukan Hukum Adat dalam Rangka Pembangunan Nasional, Bandung, Alumni, 1978.

B. Weinstein, Jack, "Some Benefit and Risks of Privatization of Justice Though ADR", Ohio State Journal on Dispute Resolution, 1996.

Bagya Agung Prabowo, M. Syamsudin, dan Mahrus Ali, 2009, Carok di Madura Studi tentang Aliran Hukum yang Dianut Hakim di dalam Memutus Perkara Carok, Penelitian Institusional, Pusat Studi Hukum Fakultas Hukum Universitas Islam Indonesia, Yogyakarta

Bambang Sambu Badriyanto, Karakteristik Etnik dan Hubungan Antar Etnik, Ringkasan Hasil Penelitian, Universitas Jember, tt

Bambang Sunggono, Metodologi Penelitian Hukum, Cetk. Keempat, Jakarta, RajaGrafindo Persada, 2002.

Barda Nawawi Arief, "Mediasi Penal dalam Penyelesaian Sengketa di Luar Pengadilan", makalah disampaikan pada Seminar Nasional Pertanggungjawaban Hukum Korporasi dalam Konteks Good Corporate Governance, Program Doktor Ilmu Hukum UNDIP, Jakarta, 27 Maret 2007

Code, David, "The Paradox of Race and Crime: a Comment on Randall Kennedy's "Politics of Distinction", Georgetown Law Journal, No. 83, 1995

E. Farbiarz, Russell, “Victim-Offender Mediation: A New Way of Disciplining America's Doctors", Michigan State University Journal of Medicine E Law, No.12, 2008.

E. Laflin, Maureen, "Remarks On Case-Management Criminal Mediation", Idaho Law Review, No. 40, 2004.

Ellen Reimund, Mary, "Confidentiality in Victim-Offender Mediation: A False Promise?", Journal of Dispute Resolution, 2005.

, "Mediation in Criminal Justice: A Restorative Approach", Advocate, No. 46, 2003.

Gerarda Brown, Jennifer, "The Use of Mediation to Resolve Criminal Cases: A Prosedural Critique", Emory Law Journal, No. 43, 1994.

H. Shenk, Alyssa, “Victim-Offender Mediation: The Road To Repairing Hate Crime Injustice", Ohio State Journal on Dispute Resolution No. 17, 2001 
H. Teninbaum, Gabriel, “Easing The Burden: Mediating Misdemeanor Criminal Matters", Dispute Resolution Journal, No. 62, 2007

Hasan Alwi, Kamus Besar Bahasa Indonesia, Edisi Ketiga, Jakarta, Departemen Pendidikan Republik Indonesia dan Balai Pustaka, 2001.

Levine, Adina, “A Dark State of Criminal Affairs: ADR Can Restore Justice to the Criminal "Justice" System", Hamline Journal of Public Law and Policy, 2003.

M. Widman, Stuart, "The Protections and Limits of Confidentiality in Mediation", Alternatives to the High Cost of Litigation, November, 2006.

Mahrus Ali, Dominasi Hukum Negara dalam Penyelesaian Perkara Carok Studi Konstruksi Penyelesaian Perkara Carok Berdasarkan Nilai-nilai Budaya Masyarakat Madura, Tesis, Program Pascasarjana Fakultas Hukum Universitas Islam Indonesia, Yogyakarta, 2009

Mien Ahmad Rifai, Manusia Madura Pembawaan, Perilaku, Etos Kerja, Penampilan, dan Pandangan Hidupnya seperti Dicitrakan Peribahasanya, Yogyakarta, Pilar Media, 2007.

N. Glaser dan Moynihan (Eds), Ethnicity: Theory and Experience, Cambridge, Harvard University Press, 1981.

Otje Salman Soemadiningrat, Rekonseptualisasi Hukum Adat Kontemporer, Bandung, Alumni, 2002.

Peter Mahmud Marzuki, Penelitian Hukum, Cetk. Kedua, Jakarta, Kencana, 2006.

Sahetapy, Kausa Kejahatan dan Beberapa Analisa Kriminologik, Bandung, Alumni, 1981.

Simms, Larysa, "Criminal Mediation is The Base of the Criminal Justice System: Not Replacing Traditional Criminal Adjudication, Just Making it Better", Ohio State Journal on Dispute Resolution, No. 22, 2007.

Soetandyo Wignjosoebroto, Hukum, Paradigma, Metode dan Dinamika Masalahnya, Jakarta, HuMa, 2002.

Wellikoff, Ilyssa, "Victim-Offender Mediation and Violent Crimes: On the Way to Justice", Cardozo Online Journal of Conflict Resolution, No. 5, 2004.

William Bakker, Mark, "Repairing The Breach and Reconciling the Discordant: Mediation in the Criminal Justice System", North Carolina Law Review, No. 72, 1994. 
